\title{
40 years of the Surface Mining Control and Reclamation Act (SMCRA): what have we learned in the State of Wyoming
}

\author{
Brenda K. Schladweiler ${ }^{1}$
}

Received: 6 October 2017/Revised: 4 January 2018/Accepted: 9 January 2018/Published online: 29 January 2018

(C) The Author(s) 2018. This article is an open access publication

\begin{abstract}
The Surface Mining Control and Reclamation Act (SMCRA) was enacted in 1977 and was the overriding federal regulation governing mining and reclamation of surface coal mines in the United States of America (USA). Many of the newest surface mines in the USA, at that time, were in the western portion of the nation. Wyoming surface coal mines numbered approximately 20 and were located throughout the state in the coal bearing regions, generally in the south/southwestern portion of the state and the northeastern corner. The Office of Surface Mining Reclamation and Enforcement (OSMRE) is the federal agency tasked with oversight of the implementation of SMCRA. Individual states developed statewide programs that met or exceeded the requirements of SMCRA and, thus, obtained primacy over coal mine mining and reclamation within their boundaries as long as those regulatory conditions were maintained. OSMRE retained oversight on the Indigenous Nations programs within the USA. Much information has been learned on the reclamation side of SMCRA, its regulations and state programs since its passage. This paper and presentation will present some of the basic changes made in reclamation programs over the last 40 years in the State of Wyoming.
\end{abstract}

Keywords Regulatory · Policies · Historical changes

\section{Introduction}

Many environmental issues, including those related to surface mining in the United States of America (USA), were being addressed by the federal government in the late 1960 's and 1970's. However, reclamation was not new to the mining industry. Wyoming reclamation laws pre-dated the federal Surface Mining Control and Reclamation Act
(SMCRA) of 1977. The Open Cut Land Reclamation Act of 1969 and the subsequent Environmental Quality Act of 1973 provided a regulatory framework for state oversight of surface mining, and, in particular, coal mining. Some researchers and agency personnel understood the vast coal resources in Wyoming and the need for such a framework (Thilenius and Glass 1974).

Brenda K. Schladweiler

bschladweiler@bksenvironmental.com

1 BKS Environmental Associates, Inc. and Accord Resource Solutions, LLC, P.O. Box 3467, Gillette, WY 82717, USA 


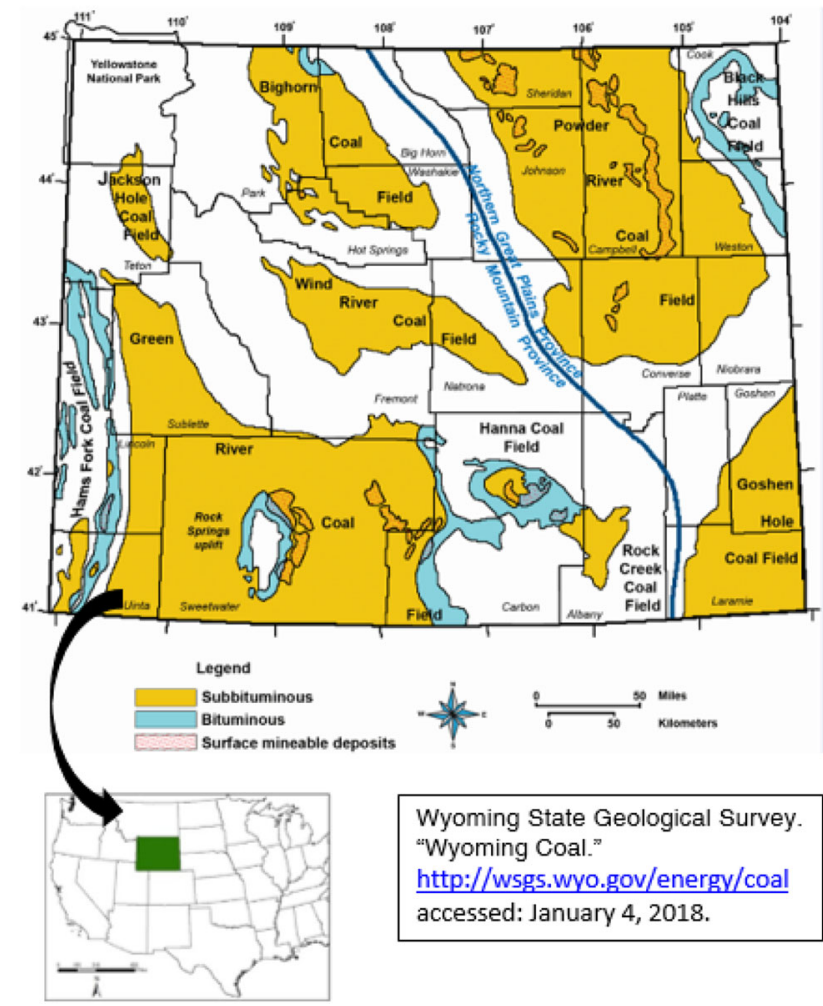

The Office of Surface Mining Reclamation and Enforcement (OSMRE) is the federal agency tasked with oversight of the implementation of SMCRA. The federal government allows those states with surface coal mines to meet or exceed their implementation of the regulations and attain "primacy". States in the Eastern USA have slightly different requirements than the Western United States, e.g., length of the bonding period being 5 years instead of 10 .

Learning curves abounded in the late 1970's and 1980's for industry, regulators, researchers and service providers. Much research was carried out during the late 1980's and early 1990's in Wyoming under the Abandoned Coal Mine Land Research Program.

On the 40th anniversary of SMCRA, the author reflects on the knowledge gained over this time. In addition, several people knowledgeable in past or current reclamation efforts were interviewed for insight into the extent of "what we have learned". Much of this information is from the Western USA and, in particular, the State of Wyoming (where mines in 1977 were relatively new). The following general categories of knowledge were discussed in the present paper.

\subsection{Influence of agriculture}

Many of the early reclamation-based regulations were influenced by agricultural practices in place at the time.
Reclamation was considered a phase of mining and not necessarily a field of science in its own right. A simplistic way of looking at reclamation was "just getting something to grow and stabilize a site". In the Eastern United States, that meant forested lands and subsequent land use. In the Western United States, the dominant land uses were grazing lands for domestic livestock and wildlife habitat. Prime farmland was a part of the Midwestern United States, and cropland and hayland were dominant uses.

Eventual knowledge of seeding drastically disturbed lands did not necessarily mirror agricultural systems in the following ways.

\subsubsection{Seed mixes}

Seed mixes were rudimentary and much less diverse in 1977. The emphasis was on commercially available seed and quick-establishing plants with little understanding or regard to inter- and intraspecific species competition. Ecological diversity, longevity and wildlife habitat value were often secondary considerations. Species such as crested wheatgrass (Agropyron cristatum) and smooth brome (Bromus inermis) (often used for pasture grass) were commonly used in reclamation but are now considered invasive and thus undesirable. Commonly seeded legumes were also agriculturally-based, i.e., alfalfa (Medicago sativa) and yellow sweetclover (Melilotus officinalis).

Since 1977, the seed industry has essentially "caught up" to market demands. Natural Resource Conservation Service (NRCS) Plant Material Centers throughout the Western USA developed hardy and prolific varieties of commonly seeded grasses, especially cool-season perennial grasses such as wheatgrasses. Many of these have the ability to outcompete other perennial grasses, forbs and shrubs; therefore, their overall use is now more limited. The seed for many warm season grasses such as blue grama (Bouteloua gracilis) was not commercially available and, until wildlife habitat for species of concern became an issue, the use of perennial forbs was limited. Commercial availability of perennial forb seed was also lacking.

In the late 1970's seed sources were limited, as were plant varieties. Markets for seed that could tolerate colder northern climates had not generally been developed prior to SMCRA. Often, seed sources were from more southern climates which, when planted in the north, caused many of the germinating seedlings to winter-kill or die. The push for adapted seed began in the mid-1980's. Hand collection of the less commercially available forb seed began about that time frame; however, such seed was costly and supplies limited but, in many ways, still is. 


\subsubsection{Seeding equipment}

Many of the early seed drills, used for grains and other agricultural crops, were used for seeding reclaimed ground. Much of this ground was rocky with large clods of soil which caused problems for traditional agricultural equipment. Rangeland seeders have now been developed to handle the rockier soil.

In agriculture, a smooth firm seed bed is desirable. While that is still the case for flatter reclaimed areas, the likelihood of flat, smooth, clod-free seed beds in drastically disturbed areas is less likely. Rough is now considered better in some situations, especially steep slopes, especially those exposed to wind or water erosion. Therefore, pitters or imprinters can be helpful equipment in those instances, especially if followed with broadcast seeding/chaining to get good seed/soil contact.

The type of seed also made it difficult for passage through many traditional agricultural drills. Fluffy (trash) perennial grass seed (and some shrubs) containing awns and brackets did not feed adequately through seed chambers and tubing on drills. A new generation of drills was created by manufacturers to handle trash seed.

Broadcasting of shrub and forb seed was later found to improve chances of survival of those life forms. Seeding of shrubs and forbs, if drill seeded with perennial grasses, did not allow long-term survival of these species with the overly competitive cool-season grasses.

\subsubsection{Soil amendments}

Nitrogen application was once a commonly applied fertilizer to reclaimed systems in the Western USA, especially if used in conjunction with surface hay or straw mulch. However, such applications were found to encourage annual weed growth and, if misapplied, could cause nitrate pollution of nearby waterways. Its use in many reclaimed areas is now discouraged. Phosphorus, on the other hand, can stimulate root growth, and, where limiting in the system, is a beneficial fertilizer.

In a semi-arid/arid environment such as Wyoming, topsoil is limiting. The dark, rich in organic matter soils, such as those found in the Midwestern USA, is limited to the extreme eastern edge of Wyoming. Every effort is made to salvage all available material suitable for plant growth. Organic matter is considered a precious commodity. However, knowledge of how much organic carbon is needed to initiate or maintain nutrient cycling has changed since 1977; a much smaller percentage of organic carbon is necessary (Ingram et al. 2005). This, however, does not negate the continued and judicial salvage of topsoil.
Understanding of the biotic component of soil was limited in 1977, especially as it related to mine land reclamation. The reestablishment of the soil biota and a functioning soil ecosystem is important to the nutrient cycling mentioned above. Organic fertilizers is an acceptable method of reestablishing this important community.

Mulching, in the form of native hay or straw, was once widely used but is now limited. Although native hay can be a desirable seed source, straw seed germination can have a deleterious effect from volunteer individuals during subsequent growing season. The high $\mathrm{C}: \mathrm{N}$ ratios found in straw material degrade slowly over time, especially in semi-arid/arid environments such as Wyoming.

\subsubsection{Weed control}

As in most agricultural systems, weeds were often considered a negative aspect of plant growth and measures were taken to control them chemically (through herbicides) or mechanically (through mowing). In semi-arid/arid environments, weeds can play a vital successional role. However, it is important to distinguish the type of weed, i.e., non-noxious annuals or noxious perennials. The former can provide some beneficial temporary aspects to reclamation such as shade for new seedlings with reduced surface temperatures, as well as reduced soil erosion and reduced grazing pressure. In addition, they can provide snow-catch in the winter time and improve soil moisture. Noxious perennials can outcompete native plants, reduce species richness of desired perennials, and provide many more negatives than positives to desirable plant growth (Hejda et al. 2009).

Since 1977, new invasive annual grasses such as cheatgrass (Bromus tectorum) have provided extreme challenges to reclamationists (Gasch et al. 2013; Rimer and Evans 2006). More recently Ventenata grass (Ventenata dubia) and medusahead (Taeniatherum caput-medusae) have caused new concerns. Immediate control of small populations is often the best defense for such aggressive annual grasses. Once established, control can be problematic and often takes a multi-step, multi-year approach to significantly reduce or control invasions of these annual grasses (Kettenring and Adams 2011).

\subsection{Wildlife habitat}

Much has changed since the days in the 1970's when reestablishment of wildlife habitat was questioned. Doubt existed that large ungulates such as Pronghorn Antelope and Mule Deer would utilize and repopulate reclaimed areas in Wyoming. In addition, no one foresaw that species considered potentially threatened or endangered, such as Sage-grouse, by the U.S. Fish and Wildlife Service would 
lead much of the research conducted today. Some considerations for wildlife habitat diversity include:

\subsubsection{Shrub establishment}

As part of reestablishing the land use of wildlife habitat, full shrubs such as Wyoming big sagebrush (Artemisia tridentata wyomingensis) had to be reestablished. Such reestablishment was difficult in the northeastern corner of the state which is transitional to the high plains and prairie ecosystems to the east and north. In the early years following the implementation of SMCRA, shrubs were assumed to invade, as was evident on many go-back agricultural hayland systems in Northeastern Wyoming. Early seeding used fourwing saltbush (Atriplex canescens) as a substitute for big sagebrush. As mentioned earlier, southern sources of this seed did not allow for long-term establishment. Fall and spring seeding of shrub seed was conducted and often in the same drill rows as other plant lifeforms which often buried small seed and provided competition from perennial grasses. Winter broadcast seeding of big sagebrush and other shrub seeds is now considered a desirable method of shrub establishment.

Early on, many federal agencies were still trying to control big sagebrush through spraying, burning or chaining. It was not until much later that these practices transitioned to protecting big sagebrush stands. Since then, much has been learned about the need for such shrub patches in the landscape and associated research is still ongoing. Not all big sagebrush patches are considered equal in quality for wildlife habitat (Stiver et al. 2010).

In 1996, the Wyoming Department of Environmental Quality-Land Quality Division (WDEQ-LQD), promulgated shrub density standards for shrub reestablishment. This was part of the regulatory performance standards a mine operator is required to meet in order for a reclaimed area to be deemed successful for release of the reclamation bond. The shrub density standard joined other revegetation performance standards for plant cover and plant production that had been in place for some time under Wyoming's primacy.

\subsubsection{Landscape diversity and topsoil}

In the early implementation of SMCRA, most reclaimed landscapes in Wyoming's surface coal regions were homogenous with less steep slopes as a result of coal removal and backfill sloping, as well as even redistribution of salvaged topsoil. Despite the fact that slope configurations of 5:1 were more desirable in high rainfall climates, these less steep slopes were established in semi-arid/arid areas. Remnant high walls or scarps could not generally be left, even if they were suitable habitat for many raptors.
Currently, some (if well-planned in the mine permit and capable of demonstrating post mine stability) can be considered.

Recent changes in geomorphic reclamation has literally changed the landscape of the post-mining topography. Considerations for stabilizing drainage features allows the reclaimed area to mimic pre-disturbance stream channels.

Proper topsoil salvage and replacement was mandated by SMCRA. Direct haul of salvaged topsoil was an important consideration for the biological viability of the topsoil, as well as mine planning. Variable topsoil replacement depths are being used by some mines to create more plant diversity in the landscape and assist shrub growth.

Alleviating compaction by ripping of backfilled areas, travel paths for equipment, etc. is an important consideration. Contact between the overlying topsoil and underlying compacted layer enhances water movement and allows for plant roots to further break up those compacted zones.

Depending on the desired post-mining plant community, substrate replacement, both quantity and type, is critical. In order to get trees and some types of shrubs reestablished, it is necessary to use rockier substrate as replacement material on the reclaimed area. The uniform replacement of topsoil requirement of SMCRA did not foresee such need.

\subsection{New technology}

No one could have foreseen how new technology has changed reclamation. The application of Geographical Information Systems (GIS) query capability in evaluating landscape problems through imagery is extremely valuable. Until recently, crude topographic and aerial maps that guided our thinking have given way to those produced with the use of Light Detection and Ranging (LIDAR), satellite, digital high altitude aerial imagery and drones or unmanned aerial systems (UAS).

Global Positioning System (GPS) is used in heavy equipment to replace backfill, as well as guiding topsoil salvage and replacement operations. Post-mining topography recreation is now at the dozer-level. In conjunction with the use of extensive databases, undesirable material can now be tracked in ways never understood in 1977.

\section{What haven't we learned yet}

Regulations are often written with broad brush implications but implemented on a site-specific or regional basis. The one-size-fits-all mentality is often engrained in regulation simply as a result of the process. Complex problems deserve complex solutions and a regulatory framework that can adapt to finding those solutions. When SMCRA was 
devised, it was meant to address many of the problems in the Eastern USA. Mines west of the 100th Meridian (or essentially the Western USA) had similar categories of items to address such as topsoil salvage and stream protection but the environment was vastly different. Similarly, regions throughout the world have similar categories but their environments can be vastly different too. Fixing past problems or planning for new disturbance must take into account those regionally-specific conditions. Understanding the overall ecology of any site, its limitations and its challenges are essential to achieving success.

Site specific considerations may include:

- Are there limited resources such as seed, water, topsoil etc.?

- How can those limited resources be used or preserved most effectively?

- How can organic matter be incorporated into the system to increase soil fertility?

- Is stability a priority?

- Is another land use, such as wildlife habitat, a priority?

There is much continuing debate whether reclamation or restoration is the proper word for what SMCRA should accomplish. Ecosystem function and land uses can be restored. The restoration of late successional plant communities, however, is something that only time can provide. What then is the best means for success comparison (for bond release purposes) with a young reclaimed area? Is it a similar undisturbed vegetation community, ecological site (as defined by the NRCS), or some type of technical standard? What is a reasonable expectation of trend given the 5 and 10 year bonding time frames? That debate continues.

\section{Summary}

Most interviews agreed that technology has advanced sufficiently to provide the tools and resources needed to properly and cost-effectively reclaim a surface coal mine in Wyoming. These include, in part, available quality and quantity of seed, soil amendments, and the proper equipment. Potential variables impacting success include the pre-planning needed to maximize the efficiency of effort, the money allocated to the necessary resources, the regulatory environment that allows flexibility in implementation, and the managerial and engineering commitments to consider reclamation a vital part of the mining process. As many western mines, such as in Wyoming, have gone from being "new" in 1977 to "mature" in 2017, how are the lessons learned over 40 years recognized and applied today?

As the nations of the world utilize their natural resources for the betterment of their people, how can impact be minimized while maintaining long-term sustainable use? Reclamation definitely has a role. Mining operators and regulators in Wyoming and the semi-arid/arid Western USA have learned much in the 40 years since SMCRA was passed and implemented. According to Schroeder et al. (2016), important positives during the course of a reclamation career include "dedication to the advancement of the sciences, professionalism, inspirational mentoring, and partnerships". Wyoming's reclamation practitioners have been a resilient group of people that have met many challenges over the 40 years since the passage of SMCRA. We likely have more to learn. Our charge is to pass on the knowledge we have gained.

Open Access This article is distributed under the terms of the Creative Commons Attribution 4.0 International License (http://crea tivecommons.org/licenses/by/4.0/), which permits unrestricted use, distribution, and reproduction in any medium, provided you give appropriate credit to the original author(s) and the source, provide a link to the Creative Commons license, and indicate if changes were made.

\section{References}

Gasch CK, Enloe SF, Stahl PD, Williams SE (2013) An abovegroundbelowground assessment of ecosystem properties associated with exotic annual brome invasion. Biol Fertil Soils 49:919-928

Hejda M, Pyšek P, Jarošík V (2009) Impact of invasive plants on the species richness, diversity and composition of invaded communities. J Ecol 97(3):393-403

Ingram LJ, Schuman GE, Stahl PD, Spackman LK (2005) Microbial respiration and organic carbon as indicators of soil quality and nutrient cycling in reclaimed soils. Soil Sci Soc Am J 69:1737-1745

Kettenring KM, Adams CR (2011) Lessons learned from invasive plant control experiments: a systematic review and metaanalysis. J Appl Ecol 48:970-979

Rimer RL, Evans RD (2006) Invasion of downy brome (Bromus tectorum L.) causes rapid changes in the nitrogen cycle. Am Midl Nat 156:252-258

Schroeder S, Toy T, Vories K (2016) Challenges and opportunities: reflections on a life in mined land reclamation. Reclamation matters. Spring 2016, pp 10-18. http://www.asmr.us/Publica tions/Reclamation-Matters

Stiver SF, Rinkes ET, Naugle DE (2010) Sage-grouse Habitat Assessment Framework. U.S. Bureau of Land Management. Unpublished Report. U.S. Bureau of Land Management, Idaho State Office, Boise, Idaho

Thilenius JF, Glass GB (1974) Surface coal mining in wyoming: needs for research and management. $J$ Range Manag 27(5):336-341 